\title{
Religion and Politics: Contestation, Protest and Reform of Jama'at-i-Islami in Kashmir
}

\author{
Shahid Maqbool \\ M. Phil., Department of History and Culture, Jamia Millia Islamia, New Delhi
}

\begin{abstract}
Religion has always been part and parcel of every society. It has witnessed many reforms within and from outside. The notion is also applicable in the context of Kashmir. Historically speaking, Kashmir has been abode of many cultures and faiths incorporating in it the syncretic religious tendencies. Kashmir, which was predominantly a Hindu society in the twelfth century, became a Muslim majority region by the turn of sixteenth century as a result of missionary work done by Sufis and local Rishis. Despite mass conversion of Kashmiris to Islam, many pre-Islamic practices continued among the Muslims of Kashmir. As a result, Islamic reform movements took their inception in an organized way from the beginning of twentieth century. In the midst of these reform movements Jama'at-i-Islami in Kashmir was a departure rather than continuation from the existing movements both in terms of ideology, methodology and reform. Consequently, a new orientation of Islam in terms of politics was asserted for the first time in the context of Kashmir. The Jama'at-i-Islami displayed their contestation and protest against not only the prevailing pre- Islamic practices among Muslims, but also against the prevailing notion and interpretation of Islam. However, the methodology adopted by Jama'at in their struggle for bringing their ideology to the central landscape of religion was based on tactical compromises and methodological transformations. This proved to be an important factor for the congenial results for them and consequently they are continuing to influence a large section of population in Kashmir. Qualitative analysis was done to analyze the cause and effect of Jama'at movement in the valley of Kashmir. The result shows that changing tactics as per impeding circumstances has been instrumental for Jama'at's success in terms of contestation, protest and reform.
\end{abstract}

Key Words: Jama'at-i-Islami, Religion, Political Islam, Contestation, Reform

\section{Introduction}

The Kashmir valley is one of the most prominent Muslim majority areas in the Sub-continent with not less than $94 \%$ of the Muslim population according to the earliest available census report. ${ }^{1}$ This remarkable change in the religious demography of Kashmir occurred especially during the fourteenth, fifteenth and sixteenth centuries following mass conversion to Islam. It should be mentioned that except for a few immigrants the predominant majority of Kashmiri Muslims are converts from Hinduism and a thin slice from Buddhism. ${ }^{2}$ As a matter of fact, conversion to Islam remained a far-fetched dream, never realized at any stage of Kashmir history till our own times. Except for a few people, conversion could not prove closer to Nock's definition as "reorientation of the soul- a turning which implies a consciousness that a great change is involved", ${ }^{3}$ especially when we consider that Islam demands from its adherents a total transformation after its comprehensive code of life and world view, as Quran says, "O ye who believe, enter whole heartedly into Islam."4 Walter Lawrence depicts the distance of Kashmiri Muslims from the real Islam and their continued traditional Hindu practices as: "The Kashmiri Sunnis are only Musalmans in name. In their hearts they are Hindus, and the religion of Islam is too abstract to satisfy their superstitious cravings, and they turn from the mean priest and the mean mosque to the pretty shrines of carved wood and roof bright with the iris flowers where the saints of past time lie buried... In connection with the suggestion that the Kashmiris are at heart Hindus, it may be mentioned that the certain places are held in reverence by Hindus and Musalmans alike. As an instance, at Fattehpura in the Vernag Ilaka, and at Waripura in the Magam Ilaka, I have seen the imprint of a foot in a stone worshipped by the Musalamans as Kadam-i-Rasul (the Prophet's ${ }^{\text {(p.bu.h) }}$ footprint), and by the Hindus as Vishna Pad (Vishnu's foot)." ${ }^{, 5}$

\footnotetext{
${ }^{1}$ Census of India, 1911, p. 88.

${ }^{2}$ Muhammad Ashraf Wani, Islam in Kashmir (14 $4^{\text {th }}-16^{\text {th }}$ century), (Srinagar: Oriental Publishing House, 2005), p. v.

${ }^{3}$ A.D. Nock, Conversion: The Old and New in Religion from Alexander the Great to Augustine of Hippo (New York: Oxford University Press, 1933), p. 7.

${ }^{4}$ Al-Qur'an, Surah Baqarah, 2:208.
} 
Walter Lawrence also writes: "The people believe that a visit to the shrines will secure the object of their wishes. Sick men will regain health, women will be vouchsafed children, and the litigant will win his case, if a pilgrimage be made to Chhrar Sharif or any of the leading shrines. The white rags which are tied to the shrines are placed there by supplicants for offspring, and till a child is born the rag is left in its place."

The above mentioned milieu prepared the ground for the genesis of Islamic Reformism, against the religious innovations, from the twentieth century in an organized way. The pioneering efforts in this regard was made by Mawlana Rasool Shah (1855-1909), the then Imam of Jamia Masjid Srinagar. He founded Anjumani Nusrat-ul-Islam in 1899. ${ }^{7}$ The nature of Anjuman-i-Nusrat-ul-Islam remained socio-political with main emphasis on the balance of modern and religious education. ${ }^{8}$ However, its objectives were clearly devoid of political Islam and never claimed to establish an Islamic state. Islam and politics was separate domain for them. It on the other hand, declared itself as 'welfare oriented party'. ${ }^{9}$ These Maulanas were the leading figures of Jammu and Kashmir Muslim Conference, which played pioneering role in the freedom struggle of Kashmiri people (against Dogra rule). ${ }^{10}$ Another reformist movement in the Kashmir was Anjuman-i-Ahli Hadith. Ahl-iHadith is a later $19^{\text {th }}$ and early $20^{\text {th }}$ century Islamic movement in the Indian subcontinent. ${ }^{11}$ It preached or rather re-asserted the Quranic message of un-compromising monotheism. The Ahl-i-Hadith unfailingly underlined the need to accept only the original sources incorporating the fundamentals of Islam, and therefore, may rightly be called as representing the "fundamentalist orientation in modern period. ${ }^{12}$ Ahl-i-Hadith was inspired by the writings of Shah Walliullah (1703-1763 A.D.) of Delhi, who courageously espoused the importance of independent judgment, reasoning and ijtihad ${ }^{13}$ in religious and juridical matters. ${ }^{14}$ The Anjuman Ahl-i-Hadith was informally inaugurated and co-sponsored by Maulana Syed Hussain Batku of Srinagar and Maulana Muhammad Anwar Shah of Shopian. The Anjuman Ahl-i-Hadith Jammu wa Kashmir was formally launched by the activists of the movement in $1923 .^{15}$ The launching of this body came as thunderbolt to the United Mulladom of Kashmir. ${ }^{16}$ The Ahl-i-Hadith saw the decline of the Muslims as a result of their having strayed from the path of the Prophet (P.B.U.H) and from strict monotheism (tauhid), and notably (what they called) 'blind following' (taqleed) of the four schools of jurisprudence ${ }^{17}$ and beliefs and practices associated with Sufism. The Mullas, Muftis, Pirs and so called Saints of Kashmir declared a virtual war on the leaders and activists of Ahl-i-Hadith movement. They were subjected to bloody physical assaults. A complete social boycott was organized against them... They were not allowed to offer prayers in mosques in the Valley. ${ }^{18}$

Besides, another reformist trend Anjumn-i-Tabligul Islam took roots to counter Ahl-i-Hadith movement (and also argued against the political ideology of JIJK later on). The Anjuman-i-Tabligul Islam was founded by a group of traditionalist and orthodox Muslim theologians at Kalashpora, Fateh Kadal, Srinagar in 1932 A.D. ${ }^{19}$ The Anjuman claimed to serve the cause of Islam, in the light of Hanafi Maslak ('The Cult of Hanafi School of Thought') and Sufi Mashrab ('Sufi pathway'). ${ }^{20}$ The Anjuman struggled to conserve the historical character of Islam in Kashmir. The Anjuman hold in high esteem the local saints of the valley along with the Sufi saints who

\footnotetext{
${ }^{5}$ Walter Lawrence, The Valley of Kashmir (Srinagar: Chinar Publishing House, 1992), p. 286.

${ }^{6}$ Ibid., pp. 289-290.

7 Mushtaq Ahmad Wani, Muslim Religious Trends in Kashmir in Modern Times (Patna: Khuda Bakhsh Oriental

Public Library,1997), p. 22.

${ }^{8}$ Monthly Nusrat-ul-Isam, 1984.

${ }^{9}$ Anjuman-i-Nusratul Islam, Srinagar, Annual report, 1953, 54, 55, 56, p. 6.

${ }^{10}$ Wani, op. cit., p. 26.

${ }^{11}$ For detailed account of the origin and development of Ahl-i-Hadith movement see: Shah Anayatullah, Ahl-iHadith, in Encyclopedia of Islam ( $2^{\text {nd }}$ Ed.), Vol. 1, Leiden, 1960, pp. 259-260.; Bashir Ahmad Khan,“Ahl-iHadith Movement in Kashmir (1901-1981)", (M.phil Dissertation), P.G. Department of History, University Of Kashmir; Mir Maulana Mohammad Ibrahim Sialkoti, Tarikh-Ahl-i-Hadiyh, New Delhi, 1953.

${ }^{12}$ Wani, op. cit. p. 34.

${ }^{13}$ Using independent reasoning and logic to solve a problem, whose solution is not directly mentioned in Quran and Sunnah, but at the same time not violating the commandments of Allah and Prophet Muhammad (S.A.W).

${ }^{14}$ Wani, op. cit., p. 34.

15 Ibid., p. 38.

16 Ibid., p. 39.
}

${ }^{17}$ The four fiqhs or schools of legal interpretation named after their respective founders the Hanafite named after Abu Hanifa, the Shafite after Muhammad bin Idris Al Shafi, the Malikite after Malik ibn Anas and the Hanbali named after Ahmad ibn Hanbal. The School differ significantly on matters of legal provenance though all broadly unanimous on doctrinal issues.

${ }^{18}$ Wani, op. cit., p. 39.

${ }^{19}$ Ibid., p. 46.

${ }^{20}$ Ibid., p. 51. 
came from outside. ${ }^{21}$ The Anjuman stands for the separation of politics and religion and emphasizes the spiritual and moral function of religion as against its socio-political role. ${ }^{22}$

All these Islamic Reform movements focused on certain patches of Islam, for example Anjuman-iNusrat-ul-Islam's main focal point remained on education, besides filling the cadres of Muslim conference, a secular organization. On the other hand, Anjuman-i-Ahli Hadith only took their field against prevailing religious innovations and mainly focused on the ritual aspect of Islam. Anjuman-i-Tabhligul Islam revered Sufi path. As a matter of fact, none of them took all the aspects and fields of Islam to be reformed. It was between these trends, JIJK took its roots in the valley as a departure both in terms of ideology and methodology. They were the first to assert Political Islam and rather than picking up few patches of Islam focused on the entire Islamic arena and asserted Islam as a complete way of life (Mukamal Zabitah Hayat).

The Jama'at-i-Islami Jammu and Kashmir (JIJK) was founded by three individuals namely Sa'duddin, Ghulam Ahmad Ahrar and Qari Saifuddin under the influence of literature and ideology of Maulana Maududi, a twentieth century Islamic ideologue, revivalist and political thinker. For Maulana Maududi, Muslims, as such, needed to fight for establishment of a state where social, political, economic, legal, constitutional and even moral, cultural and educational matters could be resolved and settled in accordance with the Directives outlined in the Quran and Sunnah i.e., example of the Prophet Muhammad (P.B.U.H). With this basic vision and programme of action, Maulana Maududi established Jamaat-i-Islami on $25^{\text {th }}$ August 1941 in Lahore. ${ }^{23}$

The influence of Maulana Maududi's ideology disillusioned them from the concept of nationalism and thus, further alienated them from the prevailing Kashmiri leadership because of the increasing impact of nationalism (composite secular nationalism as well as Muslim nationalism) on them. Ahrar, soon became concerned about the growing influence of nationalism in the context of Kashmir. ${ }^{24}$ Sa'duddin also had realized the absence of Islamic ideals in the political agenda of Muslim Conference. He also witnessed the political rivalry between its members (especially Mirwaiz Yousuf Shah and Sheikh Muhammad Abdullah), the growing influence of secular nationalism among the political leaders of the state which had given rise to polarization within the organization as well as among the people. As such, Sa'duddin was disillusioned with the Muslim Conference for the lack of a definite program for the polity and society of the state which would be based on Islamist ideals. A clear cut example before him was the conversion of Muslim Conference into National Conference. ${ }^{25}$ Similarly, Qari Saifuddin realized the 'hollowness' in the concept of nationalism. ${ }^{26}$

Furthermore, they also realized, while getting influenced by Maulana Maududi that the efforts of earlier Islamic reform movements in the context of Kashmir had been partial for divorcing Islam and politics and not comprehending and presenting Islam as a complete way of life, which was emphatically propounded by Maulana Maududi. At the same time criticizing the other contemporary political theories and stressing the Muslims not to imitate any other system as he asserted that Islam in itself was a complete code of life (Mukamal-Zabitah Hayat) and emphasized that the objective of Muslims was Iqamat-i-din ('The Establishment of Islamic State'). The JIJK was founded by Sa'duddin, Ghulam Ahmad Ahrar and Qari Saif-ud-din in 1945 at the residence of the latter. ${ }^{27}$

The JIJK makes its ideology, goal and methodology more than clear in its Constitution. It clearly mentions in its Constitution that "the whole universe and whatever exists therein, owe their existence to God, who has created them - the Sustainer, the Controller, the Sovereign, the Law-giver, and the Lord of all."28

The Constitution further affirms faith in Allah's absolute authority over all dimensions of life i.e., social, cultural, political and economic activities and acknowledges only the "divine code rejecting any other code which is not in consonance with His Command and Guidance." 29

The constitution then goes on to discuss the objective of the JIJK, which it describes as "striving for Iqamat-i-Din i.e., establishment of God's religion, inspired by the sole desire to earn Divine pleasure and secure

\footnotetext{
${ }^{21}$ Mahfil-i-Rahmat al-lil-Aalamin, an address delivered by Syed Muhammad Qasim Shah Bukhari in Seerat convention held at Islamabad on 4 September 1988, p.4. Cited in, Wani, op. cit., p.51.

${ }^{22}$ Ibid., p.75.

${ }^{23}$ Maulana Maududi, Rudad Jamaat Islami, vol. I ( n.p, n.d), p. 3.

${ }^{24}$ Ghulam Ahmad Ahrar. Tasbeeh Roz wa Shab: Tehreek-i-Islami Jammu wa Kashmir Ka Ibtidayi door (Srinagar: Chinar Publications, 2012), pp. 22-25.

${ }^{25}$ Ashique Kashmiri, Tarikh Tahreek-i-Islami Jammu wa Kashmir: Aghaz-i-Islam se 1947 Tak, vol. 1 (Srinagar: Shoba Tasneef wa Taleef Jama'at-i-Islami Jammu wa Kashmir) op. cit., p. 278.

${ }^{26}$ Qari Saifuddin, Muhimat-i-Hayat (Srinagar, n.p, 2001), p. 23.

${ }^{27}$ Sheikh Ghulam Hassan and Abdul Hamid Fayaz, eds., Maulana Saaduddin: Hayat wa Khidmat (Srinagar: Chinar Publications, 2002), p. 11. Also see Qari Saifuddin, Muhimat-i-Hayat (Srinagar, n.p, 2001), p. 30.

${ }_{28}$ The Constitution of the Jama'at-i-Islami Jammu and Kashmir, Article 3, Part I, Department of Publications and Publicity JIJK, Srinagar, n.d. p. 4.

${ }^{29}$ Constitution, Article 3, Part I, pp. 5-7. 
success in the Hereafter." It further contends that this "Din encompasses all aspects Man's physical and spiritual life as well as his individual and collective endeavors in this life. There is not a single aspect of human life ranging from beliefs, rituals and morals to economic, social and political activities which may be outside its purview." 30

In order to establish the Din in its entirety, the JIJK constitution lays down that in the furtherance of its objectives it shall be guided only by the Quran and the Prophetic sunnah,. In this regard, the JIJK shall not, it says, 'employ ways and means against ethics, truthfulness and honesty or which may contribute to strife on earth'. It shall, on the other hand, 'use democratic and constitutional methods while working for the reform and righteous revolution'. The Jama'at shall present its Da'wah (invitation to Islam) before the whole world without any discrimination whatsoever of sect, language, colour, race, nation or country. ${ }^{31}$

The political Islam was clearly a new message and a clear cut departure rather than continuation of the prevailing reformative notion. However, JIJK's contestation, protest and reform reflected tactical strategies rather direct confrontation.

The JIJK started its journey with few individuals in the context of Kashmir and progressed slowly and steadily. It did not get the social response like a boom on the outset, because Sheikh Abdullah by that time had already been acknowledged as a mass leader in the context of Kashmir. Plus the land to tiller reform (1951) under him further strengthened his hold among the masses especially in Kashmir. So, it was not easy for JIJK to straightaway challenge the political and religious climate of the Kashmir. On the other hand, the strategy applied by the founders and the early members of JIJK was tactical. "Despite holding the stand on Kashmir as disputed," says Ashique Kashmiri, "JIJK did not come up with their stand openly keeping in view the infant stage of their organization. Further their stand on the Sufi dominated tendency in Kashmir was less virulent and in fact of friendly nature.",32 Thus, right from the outset methodology applied by Jama'at was opted on the basis of the demanding circumstances.

JIJK's approach in nullifying shirk (associating partners with Allah) and advocating tawheed (monotheism) was moderate and tactical in order to gain acceptability among the masses and unlike, Anjuman Ahli-Hadith was not of direct confrontation.

As a matter of fact, Qari Saif-ud-din (one of the founders of JIJK) was the chairman of Khanyar (a locality in Srinagar) Shrine for seven years. He also translated the Sayings of Sheikh-ul-Alam (Noor din Noorani) in Urdu. Besides, Dastoor-ul-Salateen- the Persian chronicle about the life of Sheikh Hamza Makhdum, was also translated into Urdu by the same person. ${ }^{33}$ Sa'duddin, another co-founder of JIJK, translated Aurad-i-Fattiyah of Mir Syed Ali Hamadhani in Urdu. ${ }^{34}$

The official organ of the JIJK Azan used to bring out special numbers on Sufi saints like, Shiekh-ul Alam (Noor din Noorani), Shah-i-Hamadhan (Mir Syed Ali Hamadhani) etc. ${ }^{35}$ In 1988, JIJK also opened a school Sheikh-ul-Alam Islamic Model School at Chrar Sharief in the name of famous Kashmiri Rishi Sheikh Noor-ud-din Noorani popularly known as Sheikh-ul-Alam. ${ }^{36}$

Thus, the leaders of JIJK instigated their movement with tactical moves and strategically motivated steps. And the above mentioned friendly methods regarding the highly revered Sufi saints adopted by them in contesting prevailing religious innovations substantiate the very point.

Similarly, in terms of politics, JIJK displayed the same tactical show as it did not get involved in the politics of the state directly till 1971. Rather it tried to strengthen its roots among the masses till this period through the web of its schools, darasgahas and small public libraries and reading rooms, but the fact remains that Jama'at never was apolitical in nature at any period of its growth. Rather it was passively political till 1971 and became actively political after 1971. During the early years Jamaat-i-Islami prepared and trained a team of dedicated and trustworthy cadres for future involvement in politics. Jamaat-i-Islami political character was clear by its position on the issue of accession of the state.

The party for the first time participated in the Parliamentary elections of 1971. Since then it took part in every elections up to 1977 held in the state including the Assembly elections of 1972, Bi-election of 1975,

\footnotetext{
${ }^{30}$ Ibid., Article 4, pp. 8-9.

${ }^{31}$ Ibid., Article 5, p. 9.

${ }^{32}$ An interview with Ashique Kashmiri, Srinagar, 02.10.2013.

33 Afroz Ahmad Bisati, "Religio-political role of Jama'at-i-Islami in Jammu and Kashmir" (M. Phil. Dissertation, Shah Hamadan Institute of Islamic Studies, University of Kashmir, January 1997), p. 39.

${ }^{34}$ Master Muhammad Maqbool Lone, "Maut-ul-Aalim Maut-ul-Aalam," in Hassan and Fayaz (Eds.), Maulana Sa'duddin: Hayat wa Khidmat (Srinagar: Chinar Publications, 2002), pp. 121-123.

${ }^{35}$ Some of examples are; Azan, 28 Feb. 1980, 12 Dec. 1982; 20 Jan. 1983; 15-21 Oct. 1987.

${ }^{36}$ Ghulam Muhammad Kharqah, "Maulana Saaduddin: Chand Khusgavariyan," in Hassan and Fayaz (Eds.),
} Maulana Sa'duddin: Hayat was Khidmat, op.cit., p. 157. 
Assembly election of 1977, and Assembly election of 1983. Subsequently, in 1987 it fought elections as a constituent of the Muslim united Front (MUF). ${ }^{37}$

Now the question arises "If any system other than Islamic was prohibited and if people owe their allegiance to Allah", which Maulana Maududi and Jama'at Islami had been reiterating and asserting ${ }^{38}$, then was not it self-contradictory on the part of JIJK to contest such elections under a (what they called) non-Islamic political set up?

The JIJK defends its stand of participation in the state elections as a methodological tool or as a means to an end to reach their ultimate goal or Nesb-ul Ain of Iqamat-i-Din. ${ }^{39}$ They held that in a democratic and constitutional state, the only way to change the political leadership in order to facilitate the ways of Iqama-t-Din is through elections. They further assert that using unconstitutional and undemocratic means in a democratic system to change the system is against the Jama'at's own constitution. ${ }^{40}$ Further, JIJK asserted elections can be used to generate political consciousness among the people. They held that JIJK had participated in the elections for safeguarding the democratic rights of the people as Government has failed in fulfilling its promises done to people. ${ }^{41}$ According to Syed Ali Shah Geelani, "JIJK had two basic objectives behind participating in elections. Firstly, articulation and spread of JIJK message and principles on ideological level and keep alive the 'Kashmir issue'. Secondly, to strive through democratic ways, in order to provide the masses their basic and fundamental rights". ${ }^{42}$

While using Maulana Maududi's arguments JIJK articulated in their official organ 'Azan' that 'Dawah and participation in elections should go hand in hand'. They assert that 'remaining away from elections will make Tabliegh or Dawah (preaching) irrelevant, as unless the keys of political leadership do not come in the hands of Din, the goal of Iqamat-i-Din can't be achieved'; 'religion and politics are inseparable... such an articulation becomes quite insignificant if it didn't participate in elections... The non participation of elections will surely kill the ideological distinction of Jama'at-i-Islami with the rest of the Islamic religious organizations'. Moreover, 'election nonparticipation on the part of Jama'at can make people disappointed who have been so far kept hope on us... we would be killing the choice of voters...Plus non participation will give impetus to those forces which will always try to curb Islamic forces'. ${ }^{43}$

JIJK also advocates their ideological consistency and methodological changes and defends their stand on Islamic basis. In the words of Ghulam Muhammad Bhat, former Amir-i-Jamaat, JIJK :

Islam is a religion of Hikmah (Reason/logic). It permits logical strategical change as long as such methods do not contradict with Quran and Sunnah. Prophets of Islam including Prophet Muhammad (SAW) has changed their strategies as per demanding circumstances like for example Hazrat Yousuf accepted an offer to become financial minister of an un-Islamic system. Even there are many examples when Prophet Muhammad (P.B.U.H) also made strategical changes as per demanding circumstances, for example in Sulah Hudeibiah (a peace treaty between infidels of Makkah on one hand and Prophet (P.B.U.H) and Muslims of Madinah on other hand. In this treaty Infidels displayed objection on the name Muhammad Rasoolullah (Muhammad the Prophet of God) to be written in treaty. Instead they demanded that the name be replaced by Muhammad bin Abdullah (Muhammad, the Son of Abdullah) because they do not accept him prophet. None of the companions of the Prophet dared to rub Rasoolullah. However, Prophet himself rubbed Rasoolullah and directed Hazrat Ali (R.A) to write Muhammad bin Abdullah rather than Muhammad Rasoolullah. That does not mean prophet's declaration of Prophet-hood went self-contradictory. It was in fact a methodological change as per demanding circumstances. Also other conditions of the treaty were apparently harsh for Muslims as in one of the conditions it was demanded by infidels that if any one accepts Islam among the people of Makkah and migrates to Madinah, he should be sent back. But if any amongst the Muslims of Madinah happens to come Makkah, he will not be sent back. Prophet (P.B.U.H) even accepted these conditions keeping in view long-term gains owing to which within few years The Prophet (P.B.U.H) successfully established Islamic state in the whole of the Arabia. Same has been the case of Jama'at-i-Islami --- it has changed its strategies as per demanding circumstances, keeping in

\footnotetext{
${ }^{37}$ V.B.Singh, S.Bose, State Elections in India, Data Handbook on Vidhan Sabha Elecations (New Delhi: Stage Publications, Vol.1, 1987), pp.161-165.

${ }^{38}$ For more details see Syed Abul A'la Maududi, political theory of Islam, Khilafat wa Mulukiyat, Islam ka Siyasi Nizam etc; Constitution of JIJK, Articles 3 and 4.

${ }^{39}$ An interview with Ashique Kashmiri, Former Official writer JIJK, Srinagar, 02.10.2013.

40 The Constitution of JIJK, Article 5.

${ }^{41}$ Azan, 11\&17 June, 1975

${ }^{42}$ Syed Ali Shah Geelani, Deed wa Shaneed (Srinagar: Tulu' Publications, 2006), p. 35.

${ }^{43}$ For more details see Syed Abu A'la Maududi, Tahreek-i-Islami ka Aayindah Layhe Amal (Lahore: Islamic Publications Private Limited, n.d, n.p), cited in Azan, 5-11 February, 1987.
}

\begin{tabular}{llr|} 
DOI: $10.9790 / 0837-2206078290$ & www.iosrjournals.org & 86 Page
\end{tabular}


view the longer benefits to prolong the movement in order to reach its goal of iqamat-i-din. So, there is no scope for the thinking that Jama'at has undergone ideological change". ${ }^{44}$

Thus, the election participation on the part of JIJK was also a tactical strategy and not their ideological transformation. That is why even owing formal pledge of obedience to secular constitution as members of state legislative assembly, they reverberated in the Assembly that Jammu and Kashmir was 'disputed'.

Syed Ali Shah Geelani, Jama'at-i-Islami M.L.A, in the state legislative assembly speaking on the Governors address on September 12, 1977 categorically stated that,

Accession of Kashmir to India made in 1947, under extra-ordinary circumstances was temporary and provisional. It was founded on the provision that the people of state will be given an opportunity to decide freely whether they would like to join India or Pakistan, as soon as normalcy is restored in the state. ${ }^{45}$

In line with the same stand on October 19, 1983, Syed Ali Shah Geelani declared in a press conference that the international cricket match between India and West Indies was illegal as it was being played on the 'disputed' territory of Kashmir. Since the Kashmir was unresolved, the match amounted to be a latent travesty of international law. ${ }^{46}$

It was these tactical moves that lifted JIJK from once a nascent organization (started by three individuals) to the central religio-political landscape of the valley and thus, helped it to make its impact not only in the religious arena but also as a strong political pressure group and a vital rival of the ruling parties especially National Conference that once claimed un opposed mass acceptability. This can be substantiated through following facts.

JIJK acted as a strong political pressure group against the ruling state Government (especially post 1970s) by highlighting the Government failures while meeting out the democratic and fundamental necessities of the masses. The JIJK highlighted such things in their various conventions, meetings, public conferences, resolutions, Azan and even inside state Legislative Assembly. Few instances are as follows.

The JIJK Assembly group leader, Qari Saifuddin in a written press note on $14^{\text {th }}$ May 1975, while criticizing State Government's policy of rising prices of commodities asserted that Government should before hiking the prices keep in view purchasing power of the people of the state. ${ }^{47}$ On 7 June 1975, Amir-i-JIJK, Sa'duddin in his press release asserted that the Kashmiri masses irrespective of their religions should support principles rather than persons and added that the present State Govt. has failed in its promises of curbing corruption. ${ }^{48}$

Similarly, on $9^{\text {th }}$ July, in a one day public conference of JIJK at Dooro, Syed Ali Geelani criticized State Government for promoting corruption. ${ }^{49}$ Syed Ali Geelani while speaking on the bill of illegal constructions, in the Assembly, criticized ruling party's policies in curbing it. ${ }^{50}$

On 16 August, 1988, in a Monthly meeting of District Baramulla Management of JIJK at District office Sopore, under Amir-i-Zillah (Head of a District), while discussing the State Governments negligent and favoritism policies pertaining to common issues of the people, a resolution was passed demanding solution of increasing unemployment from the state Government. ${ }^{51}$

The JIJK also highlighted the responsibilities and lapses on the part of Government through the editorials of official organ Azan in which failure of State Government's policies in curbing dishonesty, corruption, unemployment, starvations at the time of floods; ruling party's election rigging and its tactics of favoritism and partiality towards their own agents and followers; and its malfunctioning in fulfilling basic necessities to the masses like drinking, electricity etc used to be highlighted. ${ }^{52}$

The JIJK continued to use such strategies to gain mass acceptability. In this connection, JIJK also convened an international conference in 1979, in which Imam-i-Kaba was also invited. This again seems a strategic move to gain mass acceptability as Imam Kabba has a great reverence among the Muslims across the globe as in the same year some months ago on the occasion of Zulfikar Ali Butto's hanging in Pakistan JIJK property was destroyed by the people for considering Jama't-i-Islami as ally of Zia-ul-Haq for hanging Butto.

\footnotetext{
${ }^{44}$ An interview with Ghulam Muhammad Bhat, Amir-i-Jama'at, Srinagar, 14.10.2013.

45 Press conference of Syed Geelani as quoted in Azan, August, 1984.

${ }^{46}$ Azan, 20 October 1983; Sarwat Jamaal, Qisa-i-Dard (Srinagar, Shaheen Publications, 1986), p. 215.

${ }^{47}$ Azan, 15 May 1975.

${ }^{48}$ Ibid, 8 June, 1975.

${ }^{49}$ Ibid., 10 July, 1980.

${ }^{50}$ Ibid., 18 August, 1988.

${ }^{51}$ JI District Baramullah Resolution, 16 August 1988, quoted in Azan, 18 August, 1988.

52 Azan, editorials, 25 Jan. 1975; 13 August, 1977; 11 September 1980; 23 Feb. 1984; 19 Apr. 1984; 15-21 Oct. 1987; 22-28 Oct. 1987; 19 Jul. 1988; 27 Aug. 1988 etc.
}

DOI: 10.9790/0837-2206078290 $\quad$ www.iosrjournals.org $\quad 87 \mid$ Page


The most outstanding role of JIJK has been in their educational sphere. The JIJK also felt that it was only through the spread of education and literacy that its message could reach out to the general public, for published literature was its principal means of communication. ${ }^{53}$

Official historian of JIJK gives a list of some of the schools of JIJK, whose students had participated in the three year Conference of JIJK held in 1973. Even though the list does not comprise of all schools then established by JIJK, but the list surely helps in getting the educational reach of JIJK in villages and far flung areas. The list comprises the JIJK schools run at different places, like for example at Dewar Inderbud, Lalapora, Sohipora, Takipora at Lolab; Batirgam, Goshi, Trehgam, Shamnag at Kupwara; Darssu at Kralpora; Damah at Veilgam; Chogal, Hanjipat, Wahipora, Magam, Hamahpora, Dangiwacha, Braripora at Handwara; Yaru, Kahru at Langeat; Zalura, Bahrampora, Bommi, Batangu, Dangarpora, Dooru, Sehkak, Doaabgah, Muslimpir, Nichipora, Waag at Sopore; Watrahgam at Rafiabad; Tawheed Ganj, Safapora, Hajan, Ajas at Baramullah; Aarwani, Bijbehara; Bannihal; Panjurah,; Aarwani, Shopian; Nawgam, Nawab Bazar, Barbarshah, Tarahbal, Batamatoo, Shaheed Ganj, Barzulla, Kralapora, Rishi Mahala, Nawgam, Safah Kadal, Soura at Srinagar; Chrari Sharief at Budgam; Hanjura, Saalurah, Diyalgham, Salura, Shangas at Islamabad (Anantnag); at Kulgam, etc. ${ }^{54}$

The JIJK did commendable social work that made it at par with other religious organizations. In 1963, a vast area of the central District of Kashmir valley, Budgam was rocked by a series of earthquakes. The JIJK moved forward to provide relief in cash and kind, collected through donation raising campaign, to the victims without any discrimination whatsoever. The volunteers of the Organization came forward and set up shelters for those whose houses had been badly damaged. ${ }^{55}$

Similarly, during the year 1978 mysterious fires which continually broke out for months together destroyed hundreds of residential houses thus rendering thousands homeless. In that situation also the JIJK rose to the occasion and, collecting considerable relief in cash and kind, distributed it among the sufferers to help them rehabilitate. The relief in kind included cloth, bedding, building material, household commodities and medicines. The recipients of Jama'at relief as usual included the non-Muslim residents of Sangrampora, Sopore. $^{56}$

In the same way, in 1973, the JIJK through its volunteers distributed relief among the victims of the destructive floods that year. This relief, a matter of social and religious obligation, was also provided to the nonMuslim brothers of Kaloosa Bandipora whose houses had been washed away. ${ }^{57}$

In the severe floods of September-October, 1988 in the valley, JIJK distributed 100 Quintal rice among flood stricken people irrespective of any religious and sectarian discrimination. ${ }^{58}$ Similarly, on 12 October 1988 it distributed 2500 Quintal rice as kind and 45000 rupees in cash among the affected masses irrespective of religious distinctions. ${ }^{59}$ Furthermore, JIJK's sub-wing at Pulwama distributed 35 Quintal rice and 10,000 rupees among the flood stricken people. ${ }^{60}$

However, the effect of the on-field social work conducted by JIJK would have been more effective and might have turned the organization from a strong pressure group to a mass movement, had these on-field social work been conducted on regular basis. 'Consistency of on-field social activity' was what was missing in JIJK's programme. Except the above stated instances, by and large JIJK failed to use such strategies on consistent and full-fledged basis. ${ }^{61}$ Nevertheless, JIJK was successful in becoming an effective organization to influence almost all spheres of life.

By the turn of the 1970s, the JIJK had emerged as a powerful force to reckon with, with a large number of active members spread out all over the state, particularly in the Kashmir valley. In 1979, it was noted that the JIJK had managed to set up six district offices in the Kashmir province. In Srinagar district it had 44 'circles', consisting of 95 members (Arkan) with 23 more, including a woman, having applied for membership. In addition it had 700 close 'sympathizers' (hamdardan) and an estimated 6000 'supporters' (mutafiqin). In the

\footnotetext{
${ }^{53}$ Kashmiri, Tarikh, vol.2, p.101.

${ }^{54}$ Kashmiri, Tarikh, vol. 2, p. 104.

${ }^{55}$ Younus Rashid, "The Mission to Enlighten People," in Op-Ed, Greater Kashmir, Srinagar, Wednesday, 13 May 2009.

56 Ibid.

${ }^{57}$ Ibid.

${ }^{58}$ Azan, 7 October, 1988.

${ }^{59}$ Azan, 13 October, 1988.

${ }^{60}$ Ibid., 12 October, 1988

${ }^{61}$ An observation based on an interviews and extensive study of the official Organ 'Azan' of JIJK, which as a primary source substantiates that JIJK social work, except very few instances, mostly remained confined to their resolutions, conventions, conferences etc. and lacked field work and grass root activism.
}

DOI: $10.9790 / 0837-2206078290 \quad$ www.iosrjournals.org $\quad 88 \mid$ Page


course of the previous six years it had been able to reach some 50 new villages with its message. ${ }^{62}$ Because of its large size, the JIJK divided Baramulla district into two parts for the sake of administrative convenience. In Baramulla [A], it had 65 members, 199 'close sympathizers', and 525 'supporters', including 76 women; 57 new villages had been reached in the last six years. In Baramulla [B], the JIJK had 800 'close sympathizers' and some 700 'supporters'. In Islamabad [Anantnag], where the JIJK was particularly strong, there were 70 'circles', with 224 members, 7730 male and 1221 female 'close sympathizers' and 21,700 male and 3500 female 'supporters'. In the previous six years the JIJK had reached 106 new villages in the district. ${ }^{63}$

Thus, JIJK continued to play constructive role in socio-political realms and at the same time was successful in gaining a dedicated supporting cadre especially among the literate section in villages of various districts of the state such as Baramulla, Shopian, Kulgham, Pulwama, and some following in Budgam, Bandipora and Anantnag.

And this is what makes JIJK a living and an effective religio-political organization in the context of Kashmir. The basic mantra of their success has been their changing methodologies as per the impeding circumstances. And the turn of JIJK from the active politics to relatively safer aspect of Islam i.e., Dawah (preaching) and social work, in post 1997 era is also the part of the same basic mantra. The JIJK had adopted such move after facing serious repercussions, on the part of state Government, in terms of life, property etc. in the 1990 era when militant wave had become dominant wave in Kashmir and in which JIJK cadres had also got involved in one or another way. ${ }^{64}$ Thus, it was the same tactical move that in 1997 Amir Jama'at Ghulam Muhammad Bhat openly disowned Hizbul Mujahideen their militant outfit and there after comparatively drifted from the political landscape of the state. However, their mode of operation based on tactical moves keeps the question still alive that, at what time and in which circumstances they will make strong active come back in the political discourse? But the fact remains their tactical distance from the politics has given them the breathing space to increase their influence among masses through their literature, ijtemas (conferences) and social work, as Government, by and large, is not pushing a heavy hand upon them after JIJK's relatively less political activism.

Thus, JIJK is using the same breathing space to influence common people through their social works (even though yet lacking consistency in on-field social activism). In the devastating floods of Septemeber, 2014 JIJK played a vital on-field role in terms of collecting and distributing relief among flood stricken people of Jammu and Kashmir, like for example in Jammu and Reasi districts, JIJK distributed $4430 \mathrm{Kg}$ rice, $4430 \mathrm{Kg}$ flour, $185 \mathrm{Kg}$ oil, $285 \mathrm{Kg}$ salt, $197 \mathrm{Kg}$ beans, 179 blankets, 62 biscuit packets and Rs 150500 cash. ${ }^{65}$ They also established residential and medical camps in Srinagar and distributed Rs 167450 at Halqa Naid Khai, Rs 320000 at Halqa Sa'da Qadal and Rs 45000 at Halqa Harwan. ${ }^{66}$

In Kulgam district, the workers of JIJK distributed 40 Quintal vegetables, 1500 bread packs, 4000 match boxes, 2000 candles, 5000 biscuit packets, 200 Quintal rice, 2100 blankets, 250 bedding, 200 mattress, 70 bed sheets, 200 clocks, 2000 utensils, 200 pillows, 200 suits, 1500 shoes, 1000 liters oil, 22 Quintal flour, 22 Quintal beans etc. ${ }^{67}$

Similarly at Nowgham, JIJK distributed 1200 Quintal rice, 500 Quintal vegetables, 1500 liters oil, 100 Quintal beans, 10000 water bottles, 5000 blankets, 200 bundles of clothing. ${ }^{68}$ In Baramulla, JIJK distributed 667 Quintal rice, 63 Quintal vegetables, 1491 bottles of oil, 30 boxes of milk, 100 blankets, 30 sacks of flour, 3 sacks of sugar, 30 boxes of fruits, 61 liters kerosene and 320000 rupees cash. ${ }^{69}$

\section{Conclusion}

Thus, it can be concluded that JIJK emerged as new trend, in terms of political Islam, in the arena of Islamic Reformism and was, by and large, a departure rather than the continuation of the existing notions of

\footnotetext{
${ }^{62}$ Saifuddin, Wadeye Purkhar (Six Years Report Jamaat-i-Islami Jammu wa Kasmir Read at Annual Conference by Qari Saif-ud-din, the then Qaim-i-Jamaat, on September 1979 at Eid-Gah. Srinagar: Markazi Maktabah Jamaat-i-Isalmi Jammu wa Kashmir, Srinagar, (n.d)., p. 51.

${ }^{63}$ Ibid., pp. 52-3.

${ }^{64}$ Even though, JIJK never declared officially Hizbul Mujahideen (H.M) as their militant wing. However, the fact remains that the cadres of JIJK had also got influenced by the predominant militant wave of 1990s like for example Syed Salahuddin, Commander of H.M and presently the chief of U.J.C (United Jihad Council) was a Jama'at member.

${ }^{65}$ Momin, Srinagar, 31 October, 2014.

${ }^{66}$ Ibid., 21 November, 2014.

${ }^{67}$ Ibid., 31 October, 2014.

${ }^{68}$ Ibid., 7 November, 2014.

${ }^{69}$ Ibid., 5 December, 2014 
interpretation of Islam and the nature of reform. However, JIJK's contestation, protest against the existing notion and their own mode of reform was of tactical nature which proved and is proving congenial for them in terms of results. As it was the part of the same tactical moves JIJK adopted tactical methodology in countering religious innovations; remained passively political for more than two decades from its inception and then became actively political from 1971 to 1997; and then again became passive political actors in post-1997 era till date. These tactical methodological moves have thus been instrumental for them to widen their horizon of influence.
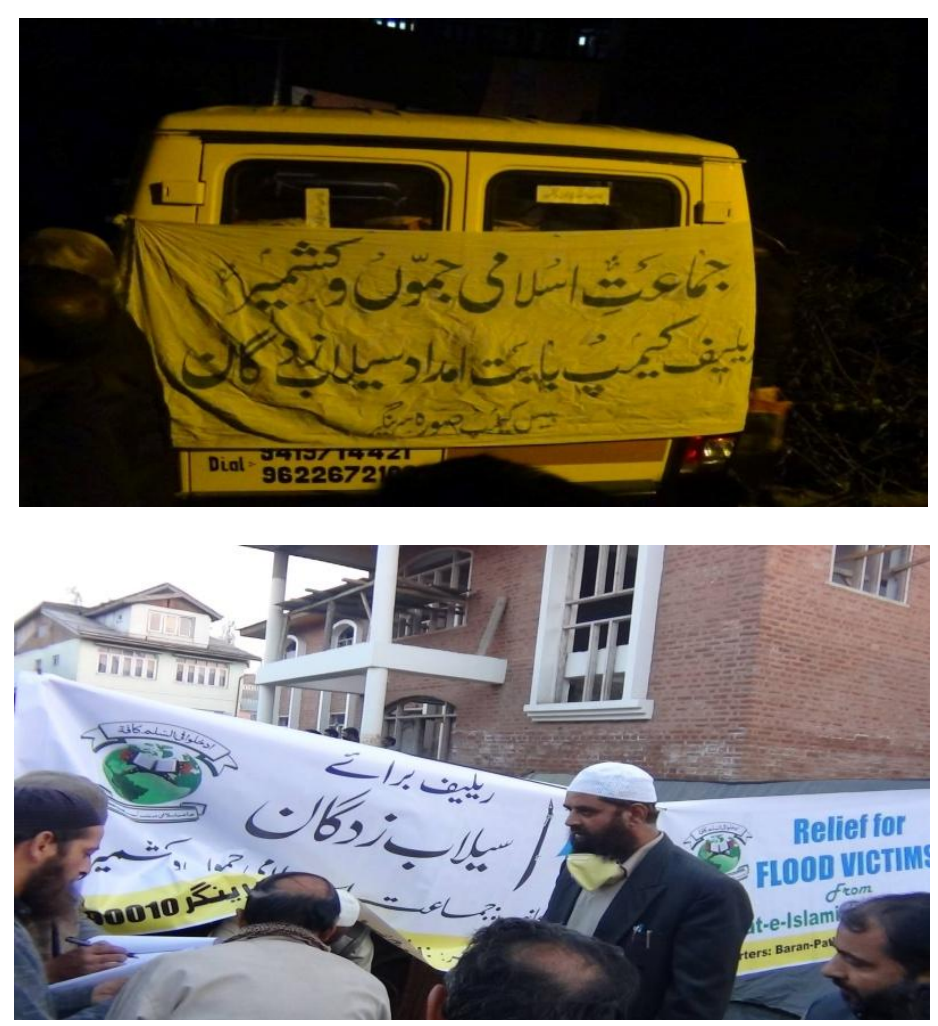

The above pictures depict the relief work undertaken by JIJK in the devastating floods (September 2014) in Kashmir 